\title{
D2 vs D2 plus para-aortic lymph node dissection for advanced gastric cancer
}

\author{
Mehmet Mahir Özmen 1,2,3 (D), Barış Zülfikaroğlu3 (D), Füsun Özmen ${ }^{4,5}$ (D), Münevver Moran ${ }^{2,3}$ (D), Necdet Özalp ${ }^{3}$ (D), Selda Seçkin ${ }^{6}$ (D) \\ 1 Department of Surgery, Medical School, Istinye University, Istanbul, Turkey \\ ${ }^{2}$ General Surgery, Liv Hospital, Ankara, Turkey \\ ${ }^{3}$ General Surgery, Ankara Numune Teaching and Research Hospital, Ankara, Turkey \\ ${ }^{4}$ Department of Basic Oncology, Cancer Institute, Hacettepe University, Ankara, Turkey \\ ${ }^{5}$ Medical Oncology, Ankara Numune Teaching and Research Hospital, Ankara, Turkey \\ ${ }^{6}$ Pathology, Ankara Numune Teaching and Research Hospital, Ankara, Turkey
}

\begin{abstract}
Objective: Gastric cancer is a common malignancy worldwide. Effective treatment by interdisciplinary cooperation is important, and surgery still plays an important role.

Material and Methods: In a ten-year period, 355 patients were diagnosed to have gastric cancer. One hundred and sixty-two patients with a median (range) age of 58 (23-83) years were eligible for the study. There were 107 patients in D2 and 55 patients in D2 lymphadenectomy plus para-aortic lymph node (PALN) dissection group. The two groups were compared in terms of complications, morbidity, mortality and long-term survival.

Results: Length of stay was 12 (8-34) days for D2 and 14 (8-42) days for D2 plus PALND. Total number of operative mortality was 8/162 (5\%), and it was not different between the groups. Twenty patients (18\%) had complications in D2 group and 9 (17\%) patients in D2 plus PALND group. Overall survival was also similar between the groups, but patients with T3-T4 tumors, patients with stage IIIA and IIIB disease had better survival with D2 plus PALN dissection. We found that the depth of invasion, PLN, ratio (PLN/TLN), stage and LND were all prognostic variables.

Conclusion: This study showed that D2 plus PALN dissection for advanced gastric cancer can be performed as safely as a standard D2 dissection by experienced surgeons without increasing postoperative morbidity and mortality. D2 plus PALN dissection should be preferred in the advanced stage of the disease (IIIA-IIIB) as it increases the rate of survival.
\end{abstract}

Keywords: Advanced gastric cancer, D2 lymphadenectomy, D2 lymphadenectomy plus para-aortic lymph node dissection, morbidity, mortality, prognosis

Cite this article as: Özmen MM, Zülfikaroğlu B, Özmen F, Moran M, Özalp N, Seçkin S. D2 vs D2 plus para-aortic lymph node dissection for advanced gastric cancer. Turk J Surg 2021; 37 (1): 49-58.

Corresponding Author

Mahir Özmen

E-mail: ozmenmm@gmail.com

Received: 06.08.2020

Accepted: 23.11 .2020

Available Online Date: 08.12.2020

O Copyright 2021 by Turkish Surgical Society Available online at www.turkjsurg.com

DOI: 10.47717/turkjsurg.2020.4931

\section{INTRODUCTION}

Gastric cancer is a common malignancy world-wide, and the 5-year survival rate in patients with gastric cancer is still poor despite improved survival due to early detection, rational lymphadenectomy and several therapeutic modalities (1). Effective treatment by interdisciplinary cooperation is important, and surgery is currently considered the best manner to treat gastric cancer. The extensiveness of lymph node dissection is, however, unclear, and there is no world-wide consensus (2-8). Extended (D2-3) lymph node dissection has improved survival in Japan $(7,9,10)$. However, the results of European studies are somewhat controversial (11-18).

Japanese surgeons first introduced the extended lymphadenectomy procedure, known today as D2, in the 1960s (19). This technique requires the systematic dissection of lymph nodes in the first tier (perigastric) and the second tier (along the celiac artery and its branches) (20). Superextended lymph node dissection (D3 dissection) has been used in advanced forms gastric cancer in many Japanese centers with the aim of eliminating metastatic lymph nodes, not only in the first and second tiers, but also in the third tier (around the upper abdominal aorta) (21).

D2 dissection for gastric cancer is a standard surgical procedure in Japan and is associated with excellent early and late results $(20,22)$, whereas it is still controversial in the West (23). All four randomized Western trials have failed to show any survival benefit for D2 dissection while finding an association between D2 dissection and 
increased morbidity and mortality $(11,12,17,18,24)$ although D2 dissection is already accepted as the standard procedure for resectable gastric cancer in many countries $(13,25,26)$.

Success with D2 resection has led to the evolution of a superextended lymphadenectomy, and several feasibility studies evaluating dissection of para-aortic lymph nodes have been performed $(6,21,27-29)$. This procedure is performed by selected centers, and D3 dissection has been practiced to improve the survival for advanced gastric cancer in these centers (21,29-31).

Very few studies from Western centers have compared D2 and D3 dissection in the surgical treatment of gastric cancer (32-34).

In the present study, we aimed to assess the value of radical surgery in gastric cancer by comparing D2 and D2 lymphadenectomy plus para-aortic lymph node (PALN) dissection.

\section{MATERIAL and METHODS}

A prospective trial was designed to compare two surgical techniques: the extended lymphadenectomy (D2) and the superextended lymphadenectomy (D2 plus PALND) for gastric cancer. Data were collected prospectively and analyzed on a retrospective manner.

Authors declared that the research was conducted according to the principles of the World Medical Association Declaration of Helsinki "Ethical Principles for Medical Research Involving Human Subjects". Written informed consent was obtained from patients who participated in this study.

\section{Patients}

In a 10-year period, 355 patients were admitted to our unit with a diagnosis of gastric adenocarcinoma.

The inclusion criteria for this study were as follows: 1) patients who received curative resection; and 2) patients who underwent extended (D2) lymph node dissection, or superextended (D2 plus PALND) lymph node dissection.

The exclusion criteria included: 1) patients who received a palliative operation; 2) patients with distant metastasis; 3) patients with intraperitoneal dissemination; 4) patients with previous gastrectomies; and 5) patients with poor performance status.

Based on the inclusion and exclusion criteria, 193 patients were excluded from the study and 162 (107 males) patients with a median (range) age of 58 (23-83) years were eligible for the study. Due to world-wide acceptance of D2 lymph node dissection (LND) as the treatment of choice, there were 107 patients in D2 and 55 patients in D2 plus PALN dissection group (Figure 1).

\section{Surgical Methods}

All operations were performed by a specialized surgical team with a standardized surgical technique.

During laparotomy, the eligibility of patients was verified by inspecting the tumor resectability, feasibility of a potentially curative resection. Depending on the tumor location in the stomach and intraoperative verification of tumor-free margins, patients were qualified for total, subtotal gastrectomy. Splenectomy was performed routinely for tumors located in the upper-third of

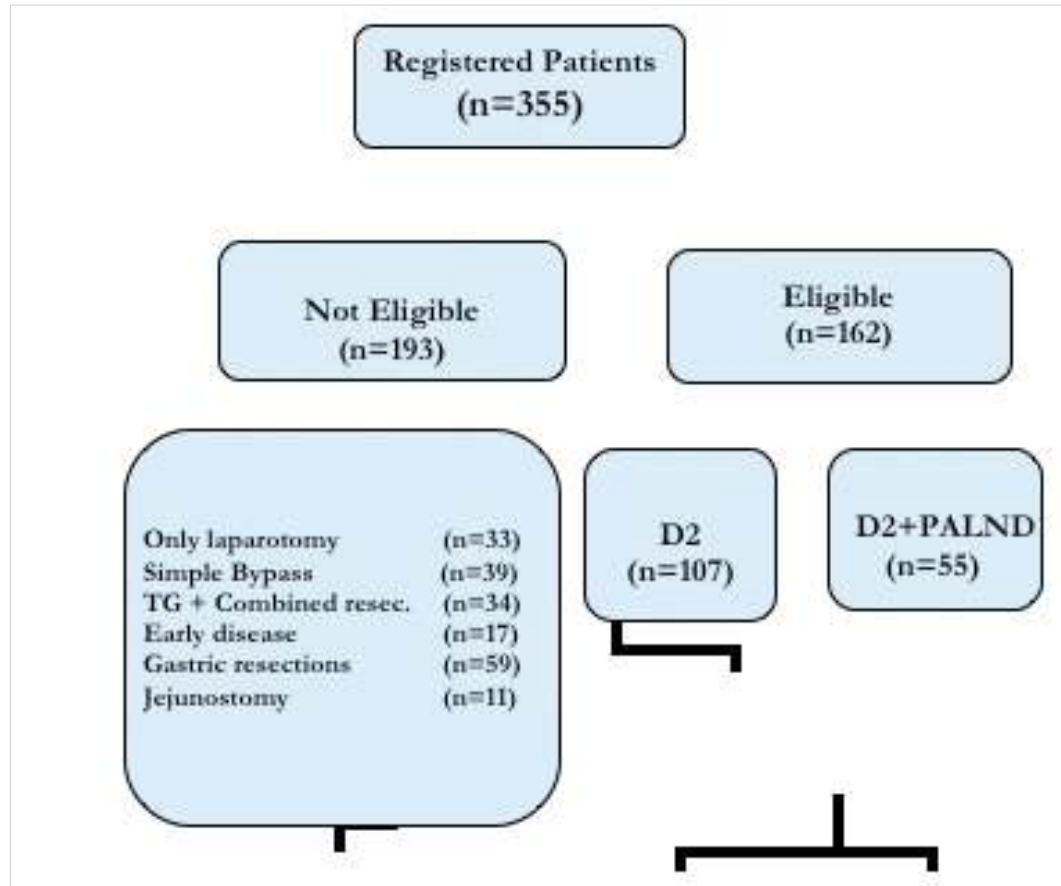

Figure 1. Categories of the registered patients, type of surgery and type of lymph node dissection. 
the stomach, and resection of the tail of the pancreas was optional. In other patients, the spleen was removed according to surgeon preference. Gastrectomy was always completed by the removal of the greater omentum and parigastric lymph nodes. The type of lymphadenectomy was selected by the surgical team according to the criteria described by the Japanese Gastric Cancer Association (JGCA) (35). The D2 lymphadenectomies were performed in accordance with the fifth English edition of the JGCA (35). D2 plus PALN dissection were performed as described previously (36).

\section{Evaluation of Operative Morbidity and Mortality}

Resected specimens were examined carefully for accurate pathologic staging according to the JGCA rules (35). The following information was included on the case report form for prospective data collection concerning the major groups of operative morbidity: anastomotic leakage, intraabdominal abscess, pancreatic fistula, pneumonia, and others (wound infection, wound dehiscence, pulmoner embolism, Ml etc.). Hospital mortality was defined as postoperative death of any cause within 30 days, death within the same hospitalization.

A follow-up of patients was performed according to our standard protocol (every 3 months for first 2 years and then every 6 months at least 5 years), which included tumor-marker studies, endoscopic examinations, ultrasonography, computed tomography, and chest radiography.

The two groups were compared in terms of complications, morbidity, mortality and long-term survival. Effect of the type of dissection as well as the diameter of the tumor, T-stage, number of total and positive lymph nodes (TLN and PLN) and survival according to tumor stage were also analyzed.

\section{Statistical Analysis}

Statistical analysis was performed using SPSS version 17.0 for Windows. Comparisons of clinicopathological differences were made using a Chi-square test for discrete variables. Rate of occurrence of events were evaluated using Fisher's Exact test. Cumulative survival rate was calculated using the Kaplan-Meier estimation and examined by the log-rank test. Survival curves compared by Chi-square test. A p-values less than 0.05 was considered to be significant.

\section{RESULTS}

Patient demographics, complications and tumor characteristics are presented in Table 1. The two groups were well balanced, as there were no significant differences in their baseline data. The age and sex distribution of the patients was comparable in both groups. Length of stay was 12 (8-34) days for D2 and 14 (10-42) days for D2 plus PALND. The total number of operative mortality was 8/162 (5\%), and it was not different between the groups. Twenty patients (18\%) in D2 group and 9 (17\%) patients in D2 plus PALND group had complications. The number of removed lymph nodes were related to dissection and it was 30(10-86) for D2 and 41 (12-98) for D2 plus PALN dissection. PLN/TLN ratio was similar in both groups (Table 1).

Patients were followed up for a period of 75 (22-130) months. We observed better overall survival with D2 plus PALND than D2 (Figure 2). Patients with T3-T4 tumors (Figures 3-4) had better survival with D2 plus PALN dissection than D2 alone. Patients with Stage IIIA also had better survival with D2 plus PALND than D2.

Although the survival rates were similar in patients with Stage I-II and IV, it was significantly better after D2 plus PALN dissection in patients with Stage IIIA (Figure 5) and IIIB disease (Figure $6)$.

We found that depth of invasion (T)( T small number 1, 2 is better than 3,4), positive lymph node (LN(-) is better), lymph node ratio ( $P L N / T L N<0.2$ is better than $>0$. 3), stage (lower the stage better the survival) and lymph node dissection (D2+ PALND is better than D2) were all prognostic variables (Table 2).

\section{DISCUSSION}

Gastric cancer still remains a major health problem, and numerous aspects of surgical treatment still remain unresolved. Despite improvements in local control and empirical chemotherapy, prognosis particularly for advance stage patients remains poor worldwide. New therapeutic strategies are needed.

Treatment of advanced gastric cancer has become much more sophisticated and complicated than ever. New directions in cancer biology research and new randomized trials promise to reach the goal of an individualized approach $(37,38)$. Recently, the decision has been reached that the only possibility for curative treatment of gastric cancer remains surgical resection. For many years, it has been debated whether an extended lymph node dissection for gastric cancer is beneficial. Theoretically, removal of a wider range of lymph nodes by extended lymph node dissection increases the chances for cure $(17,39)$. Such resection, however, may be irrelevant if there are no lymph nodes affected, if the cancer has developed into a systemic disease, or if resection increases morbidity and mortality substantially $(17,39,40)$. From this point of view, several studies have generally compared D1 dissection with D2 dissection (11-13,24). However, only a few studyies have compared D2 dissection with D3 dissection (20,27,32-34,36,41-43). Therefore, in this study, we prospectively compared D2 dissection morbidity, mortality and outcome with those of D2 plus PALN dissection.

There is a wide variation in operative morbidity and mortality following gastric cancer surgery among countries and institutions (20). The presence of comorbid disease that affects patient fitness for surgery, surgical experience of the operator, and the workload volume seem to be important factors (20). 
Table 1. Patient demographics

\begin{tabular}{|c|c|c|c|}
\hline Variable & $D 2(n=107)$ & D2+PALND $(n=55)$ & $p$ \\
\hline Age & $59.3(23-83)$ & $58(32-75)$ & ns \\
\hline $\operatorname{Sex}(M / F)$ & $76 / 31$ & $40 / 15$ & ns \\
\hline Complications & $20(18 \%)$ & $9(17 \%)$ & ns \\
\hline Wound infection & 4 & 1 & \\
\hline Leakage & 4 & 2 & \\
\hline Abscess & 4 & 2 & \\
\hline Wound dehiscence & 2 & 1 & \\
\hline Pancreatic fistula & 0 & 1 & \\
\hline Pneumonia & 4 & 1 & \\
\hline Pulmonary embolism & 1 & 1 & \\
\hline $\mathrm{Ml}$ & 1 & 0 & \\
\hline Operative mortality & $5(5.2 \%)$ & $3(4.9 \%)$ & ns \\
\hline Hospital stay (day) & $12(8-34)$ & $14(10-42)$ & ns \\
\hline Tumor size $(\mathrm{cm})$ & $7.9 \pm 3.4$ & $7.1 \pm 3.7$ & ns \\
\hline TLN & $30(10-86)$ & $41(12-98)$ & 0.02 \\
\hline PLN & $4(6)$ & $7(9)$ & ns \\
\hline PLN/TLN & $0.17 \pm 0.3$ & $0.17 \pm 0.2$ & ns \\
\hline Histologic type & & & ns \\
\hline Diffuse & 45 & 19 & \\
\hline Intestinal & 53 & 29 & \\
\hline Unclassified & 9 & 7 & \\
\hline Depth of invasion & & & ns \\
\hline $\mathrm{T} 1$ & 0 & 0 & \\
\hline $\mathrm{T} 2$ & 28 & 14 & \\
\hline $\mathrm{T} 3$ & 60 & 32 & \\
\hline $\mathrm{T} 4$ & 19 & 9 & \\
\hline Stage grouping & & & ns \\
\hline । & 0 & 0 & \\
\hline$\|$ & 29 & 14 & \\
\hline$\| I A$ & 38 & 18 & \\
\hline$\| \mathrm{B}$ & 35 & 18 & \\
\hline IVA & 5 & 5 & \\
\hline
\end{tabular}

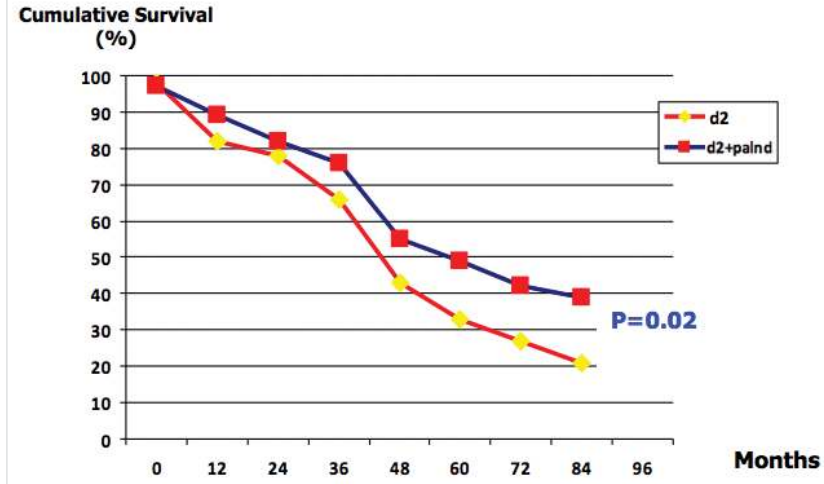

Figure 2. Overall survival curves in patients with D2 and D2 +PALN dissection.

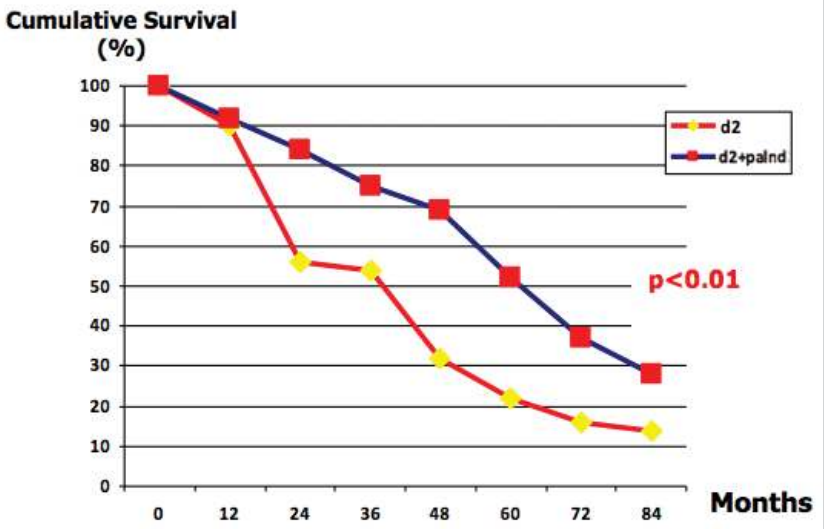

Figure 3. Survival curves in patients with $\mathrm{T} 3$ tumors. 


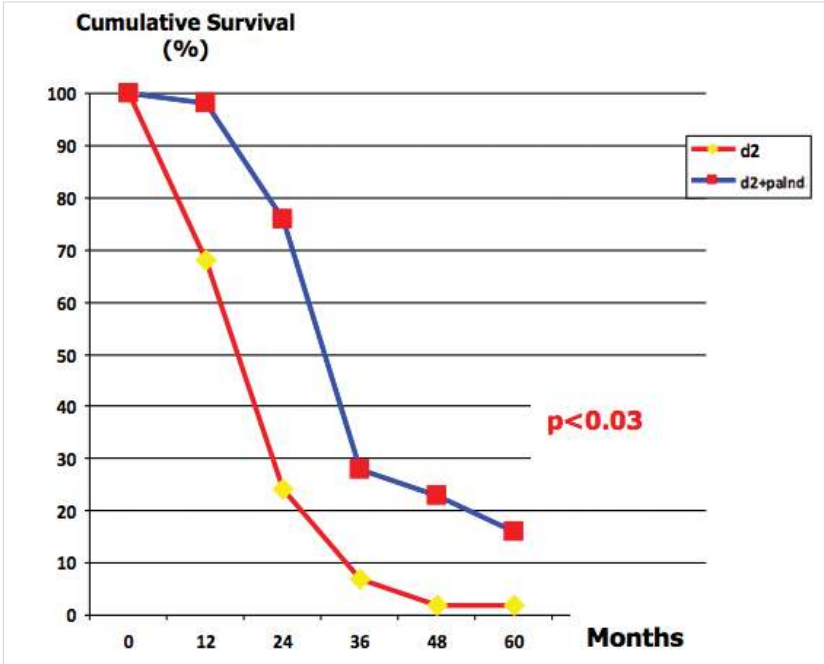

Figure 4. Survival curves in patients with T4 tumors.

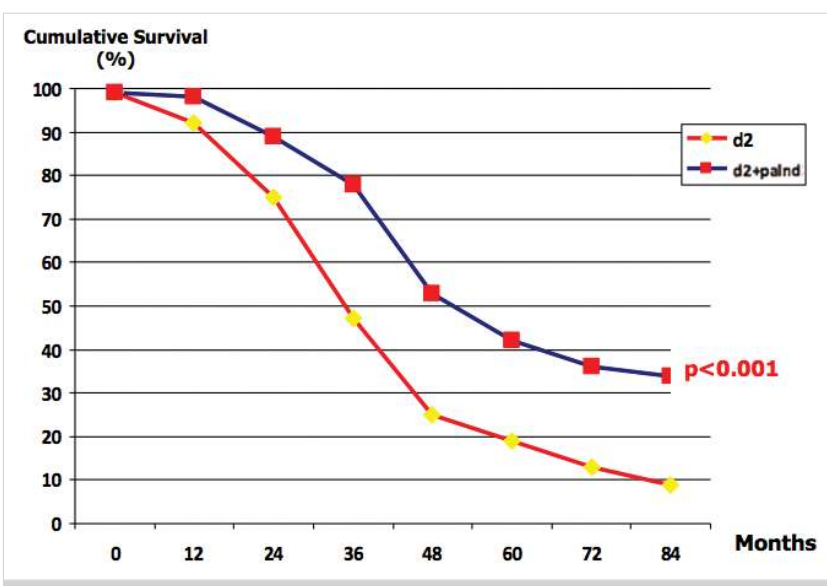

Figure 5. Survival curves in patients with stage IIIA.

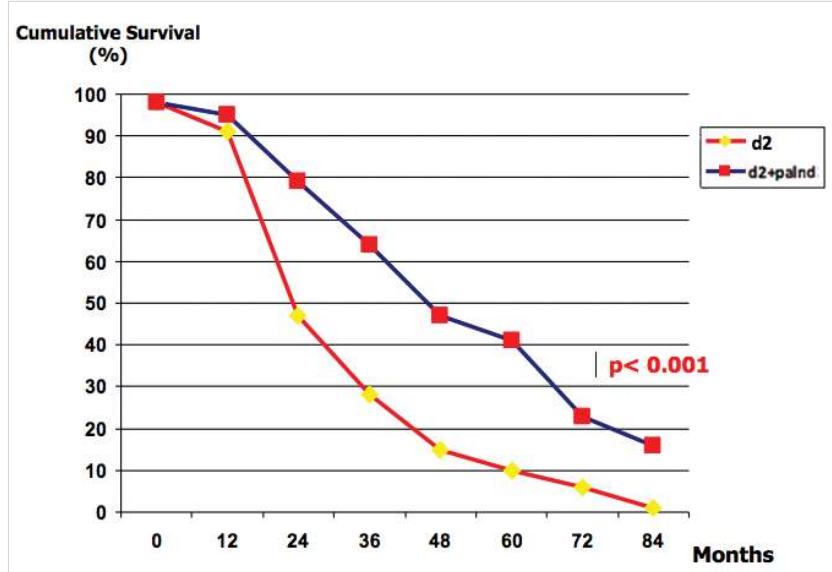

Figure 6. Survival curves in patients with stage IIIB.

of abundant data (43). For gastric cancer, only potentially curative resection (R0) achieves good outcomes, and, in view of the distribution of lymph node metastases, D1 gastrectomy is insufficient for advanced gastric cancer (41). On the other hand, safety outcomes after more extended lymph node dissection (ie, D1 vs. D3, or D2 vs. D3) were analyzed in a few studies (20, 27, 32-34, 36, 41-43, 46).

In JCOG9501 study (36), a total of 523 patients have been assigned to compare the treatment of D2 versus D3 (D2 + PALND) lymph node dissection. The results have shown that surgical mortality rate was very low in both groups (0.8\%). No significant difference was found between the two treatment groups in terms of 5-year recurrence-free survival (62.6\% vs. 61.7\%, respectively), but the overall perioperative complication rate in the D3 group was higher than that in the D2 group (28.1\% vs. $20.9 \%$, respectively) (36). These trials have shown that there was no significant survival rate benefit for performing PALN dissection in curable gastric cancer patients and simultaneously revealed its association to a higher surgical morbidity. They have reported that gastrectomy with D2 lymphadenectomy has been considered as the standard routine lymphadenectomy for locally advanced gastric cancer (36).

However, the effect of the D3 dissection on gastric cancer patients with PALN metastasis is still debatable (47). D3 lymphadenectomy may be beneficial in some patients with PALN metastasis, but more research is needed for appropriate patient selection.

Some studies have shown that incidence of metastasis to para-aortic lymph node could be around 20\% (48), and the 5-year survival rate for patients with para-aortic node metastasis undergoing para-aortic node dissection could be up to about $20 \%$. Therefore, the rationale of therapeutic para-aortic lymphadenectomy for advanced gastric cancer is suggested for further evaluations (48). D2 plus para-aortic lymphadenectomy after neo-adjuvant or conversion chemotherapy could be considered as a promising treatment for patients with para-aortic lymph nodes involved (48).

Bencivenga et al. (49) have reported that the debate concerning the role of "prophylactic" super-extended lymphadenectomy apparently came to an end after the publication of the JCOG 9501 trial that found no survival advantage when D2 lymphadenectomy was extended to PALNs in patients with T2b, T3, and T4 gastric cancer (36). Consequently, prophylactic D2 plus PALN dissection is no longer recommended as a first-choice treatment for patients with curable gastric cancer in the Japanese guidelines. However, it should be remembered that the baseline prevalence of 16 metastases in that trial was rather low (8.5\%), probably because it only enrolled patients without macroscopic metastases to PALNs, and the control group underwent D2 lymphadenectomy extended to the posterior nodal stations (12p, 13, and 14v), which are not usually resected in the case of a conventional D2 (19). 


\begin{tabular}{|c|c|c|}
\hline Variable & 5-year survival (\%) & $p$ \\
\hline Age & & ns \\
\hline$<60$ & 41.2 & \\
\hline$>60$ & 39.4 & \\
\hline Sex & & ns \\
\hline Male & 49.2 & \\
\hline Female & 51.4 & \\
\hline $\mathrm{T}$ & & 0.001 \\
\hline T2 & 52.5 & \\
\hline $\mathrm{T} 3$ & 37.4 & \\
\hline $\mathrm{T} 4$ & 19.8 & \\
\hline Histologic type & & ns \\
\hline Intestinal & 50.2 & \\
\hline Diffuse & 48.5 & \\
\hline Unclassified & 45.8 & \\
\hline Location & & 0.003 \\
\hline Upper & 37.7 & \\
\hline Middle & 50.2 & \\
\hline Lower & 61.7 & \\
\hline Stage & & 0.001 \\
\hline$\|$ & 47.4 & \\
\hline$\| \mathrm{A}$ & 28.5 & \\
\hline$\| \mathrm{IIB}$ & 25.3 & \\
\hline IV & 15.1 & \\
\hline LN & & 0.0001 \\
\hline+ & 31.3 & \\
\hline- & 64.5 & \\
\hline LN ratio (PLN/TLN) & & 0.001 \\
\hline$<0.2$ & 46.3 & \\
\hline$>0.3$ & 24.1 & \\
\hline LND & & 0.02 \\
\hline D2 & 33.1 & \\
\hline D2 plus PALND & 49.4 & \\
\hline
\end{tabular}

Liang and Deng have reported (50) the following indications for D2+PALND candidates: 1) patients in good condition with no serious organ dysfunction; 2) patients without peritoneal dissemination or liver metastases; 3) patients with pathologic N2, N3a and N3b stage disease or positive No.9 LN; 4) patients with Borrmann type III/IV disease; and 5) patients with upper-middle third or occupied more than one-third. However, they recommend that D2+PALND should be carried out only in cancer centers equipped with surgeons with extensive experience for extended LN dissections, because there are some risks in some rare situations, such as complications like formation of chylous fistula. In addition, multiple methods should be used in selecting suitable cases for further study.
Dong and Deng have also reported that (51) prophylactic D2 + PALND has not shown a survival benefit, but improved survival with therapeutic PALND may benefit from related clinicopathological factors. Then, based on the survival benefit of PALND, given that many clinicopathological factors were reported to be highly related to PALN involvement, it is necessary to verify the lymphatic flow to PALNs in gastric cancer and define accurate predictors for PALN metastasis and then explore indications for PALND. To date, CS chemotherapy combined with surgery plus extensive lymphadenectomy is considered the standard treatment for advanced gastric cancer in Japan. Therefore, neoadjuvant and adjuvant chemotherapy must not be ignored in the treatment of PALN metastasis. In the future, multimodal therapy including PALND combined with appropriate chemo- 
therapy and with other therapies, such as conversion surgery or radiotherapy, remains to be evaluated in the form of a clinical trial to obtain improved prognosis and as few complications as possible (51).

A recent study has clearly shown that standard D2 and extended D3 dissection can be performed safely without any increase in postoperative morbidity and mortality $(20,41)$. Both morbidity and mortality rates and the percentage of individual complications in our trial showed no significant differences between the D2 and D2 plus PALND groups. Hospital stay was also similar in both groups in our study. In the light of these results, we confirm that D2 plus PALN dissection may be performed in specialized centers with an acceptable operative risk.

In this study, we observed a positive linear correlation between removed lymph node and more extensive lymph node dissection (Table 1). Some authors have suggested that better disease control could be achieved through "inducing a reduction of metastatic nodes ratio" just by extending the number of dissected nodes (13,52-54). Schwarz et al. (55) believe that their results for a therapeutic benefit as a result of extended lymph node dissection, even in patients with more advanced yet resectable gastric cancer. They showed that stage-based survival prediction of advanced gastric cancer without distant metastases depends on total lymph node number and number of negative lymph nodes (55). Kunisaki et al. (43) have also shown that the incidence of lymph node recurrence in the surgically dissected area was significantly lower in D3 patients. They suggest that D3 gastrectomy might be effective for metastatic lymph nodes in the para-aortic regions (43).

In our study, we also observed a positive relation between more lymph node positivity and T-stage. Shen et al. (56) have showed that greater numbers of dissected lymph nodes could lead to a better prognosis in patients with pT3N2 disease and even in patients with pT3N3 disease. These findings indicate the important impact of thorough lymph node dissection on survival, even in patients with pT3N3 gastric cancer, who believed to have incurable disease (56).

Several papers have reported a correlation between survival benefits and D3 lymph node dissection $(20,32,41,43,57,58)$. Kunisaki et al. (43) suggest that D3 dissection may confer a survival advantage with respect to D2 dissection in patients with tumor diameters measuring 50-100 mm and pN2 disease.

In our survival analyses, we observed three results: First, better overall survival with D2 plus PALND than D2. Second, better survival with D2 plus PALND in T3-T4 tumors. Third, better mean survival and 5-year survival in stage IIIA - IIIB. This might imply that D2 plus PALN dissection does contribute to improved survival at advanced stage of gastric cancer.
In early stages of the disease, D2 is safer and better, D2 plus PALN dissection should be preferred in an advanced stage of the disease as it increases the rate of survival. Although D2 plus PALND patients had slightly longer hospital stay, extended lymph node dissection performed without any increase on morbidity and mortality.

We observed that depth of invasion $(T)$, positive lymph nodes (PLN), lymph node ratio (PLN/TLN), stage and lymph node dissection are prognostic variables. From all prognostic variables, only lymph node dissection influenced by the surgeon. Our results were in agreement with those of the Japanese and support the efficacy of extended lymph node dissection in surgical management of gastric cancer for the Western patients as well. In conclusion, this study put forth that D2 plus PALN dissection for advanced gastric cancer can be performed as safely as a standard D2 dissection by experienced surgeons without increasing postoperative morbidity and mortality. D2 plus PALN dissection should be preferred in the advanced stage of the disease (IIIA-IIIB) as it increases the rate of survival.

Ethics Committee Approval: Ethics committee approval was obtained.

Peer-review: Externally peer-reviewed.

Author Contributions: Concept - M.Ö.; Design - M.O., B.Z.; Supervision -M.Ö.; Materials - M.Ö., B.Z., N.Ö., M.M..; Data Collection and/or Processing - B.Z., N.Ö., F.Ö., M.M., S.S.; Analysis and Interpretation - M.Ö., F.Ö., B.Z.; Literature Review - M.Ö., B.Z.; Writing Manuscript - M.Ö., B.Z;; Critical Reviews - M.Ö.

Conflict of Interest: The authors declare that they have no conflict of interest.

Financial Disclosure: The authors declared that this study has received no financial support.

\section{REFERENCES}

1. Takagane A, Terashima M, Abe K, Araya M, Irinoda T, Yonezawa H, et al. Evaluation of the ratio of lymph node metastasis as a prognostic factor in patients with gastric cancer. Gastric Cancer 1999; 2: 122-8. [CrossRef]

2. Shimoyama S, Kaminishi M, Joujima Y, Oohara T, Hamada C, Teshigawara W. Lymph node involvement correlation with survival in advanced gastric carcinoma: univariate and multivariate analyses. J Surg Oncol 1994; 57: 164-70. [CrossRef]

3. Kunisaki C, Shimada H, Yamaoka H, Wagasugi J, Takahashi M, Aki-

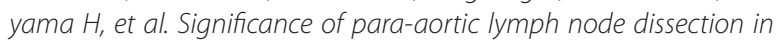
advanced gastric cancer. Hepatogastroenterology 1999; 46: 2635-42. [CrossRef]

4. Mishima Y, Hirayama R. The role of lymph node surgery in gastric cancer. World J Surg 1987; 11: 406-11. [CrossRef]

5. Maruyama K, Okabayashi K, Kinoshita T. Progress in gastric cancer surgery in Japan and its limits of radicality. World J Surg 1987; 11:41825. [CrossRef] 
6. Maeta M, Yamashiro H, Saito H, Katano K, Kondo A, Tsujitani S, et al. A prospective pilot study of extended (D3) and superextended para-aortic lymphadenectomy (D4) in patients with T3 or T4 gastric cancer managed by total gastrectomy. Surgery 1999; 125: 325-31. [CrossRef]

7. Maehara Y, Kakeji Y, Koga T, Emi Y, Baba H, Akazawa K, et al. Therapeutic value of lymph node dissection and the clinical outcome for patients with gastric cancer. Surgery 2002; 131: 85-91. [CrossRef]

8. McCulloch P, Niita ME, Kazi H, Gama-Rodrigues JJ. Gastrectomy with extended lymphadenectomy for primary treatment of gastric cancer. Br J Surg 2005; 92: 5-13. [CrossRef]

9. Kasakura Y, Mochizuki F, Wakabayashi K, Kochi M, Fujii M, Takayama T. An evaluation of the effectiveness of extended lymph node dissection in patients with advanced gastric cancer: a retrospective study of 1403 cases at a single institution. J Surg Res 2002; 103: 252-9. [CrossRef]

10. Adachi Y, Kitano S, Sugimachi K. Surgery for gastric cancer: 10-year experience worldwide. Gastric Cancer 2001; 4: 166-74. [CrossRef]

11. Bonenkamp JJ, Songun I, Hermans J, Sasako M, Welvaart K, Plukker JT, et al. Randomized comparison of morbidity after D1 and D2 dissection for gastric cancer in 996 Dutch patients. Lancet 1995; 345: 748-58. [CrossRef]

12. Cuschieri A, Fayers P, Fielding J, Craven J, Bancewicz J, Joypaul V, et al. Postoperative morbidity and mortality after D1 and D2 resections for gastric cancer:preliminary results of the MRC randomised controlled surgical trial. Lancet 1996; 347: 995-99. [CrossRef]

13. Siewert JR, Bottcher K, Stein HJ, Roder JD. Relevant prognostic factors in gastric cancer: Ten year results of the German Gastric Cancer Study. Ann Surg 1998; 228: 449-61. [CrossRef]

14. Degiuli M, Sasako M, Ponti A, Calvo F. Survival results of a multicentre phase Il study to evaluate D2 gastrectomy for gastric cancer. Br J Cancer 2004; 90: 1727-32. [CrossRef]

15. Roukos DH, Lorenz M, Encke A. Evidence of survival benefit of extended (D2) lymphadenectomy in western patients with gastric cancer based on a new concept: a prospective long-term follow-up study. Surgery 1998; 123: 573-8. [CrossRef]

16. Degiuli M, Sasako M, Calgaro M, Garino M, Rebecchi F, Mineccia M, et al. Morbidity and mortality after D1 and D2 gastrectomy for cancer: interim analysis of the Italian Gastric Cancer Study Group (IGCSG) randomized surgical trial. Eur J Surg Oncol 2004; 30:303-8. [CrossRef]

17. Hartgrink $H H$, van de Velde $C J H$, Putter $H$, Bonenkamp JJ, Klein KE, Songun l,et al. Extended lymph node dissection for gastric cancer: who may benefit? Final results of the randomized Dutch Gastric Cancer Group Trial. J Clin Oncol 2004; 22: 2069-77. [CrossRef]

18. Bonenkamp JJ, Hermans J, Sasako M, van de Velde CJH, Welvaart $K$, Songun I, et al. Extended lymph node dissection for gastric cancer. N Engl J Med 1999; 340: 908-14. [CrossRef]

19. Kajitani T. The general rules of gastric cancer study in surgery and pathology: Part 1-clinical classification. Jpn J Surg 1981; 11: 127-39. [CrossRef]

20. Sano T, Sasako M, Yamamoto S, Hashimoto A, Kurita A, Hiratsuka M et al. Gastric cancer surgery: morbidity and mortality results from a prospective randomized controlled trial comparing D2 and extended para-aortic lymphadenectomy - Japan Clinical Oncology Group Study 9501. J Clin Oncol 2004; 22: 2767-73. [CrossRef]

21. Baba H, Hokita S, Natsugoe S, Miyazono T, Shimada M, Nakano S Paraaortic lympadenectomy in patients with advanced gastric carcinoma of the upper-third of the stomach. Hepatogastroenterology 2000; 47: 893-6. [CrossRef]
22. Maruyama K, Sasako M, Kinoshita T, Sano T, Katai H. Surgical treatment for gastric cancer: the Japanese approach. Semin Oncol 1996; 23: 360-8. [CrossRef]

23. Sasagawa T, Solano H, Vega W, Mena F. The effectiveness of extended lymph node dissection for gastric cancer performed in Costa Rica under supervision of a Japanese surgeon: a comparison with surgical results in Japan. Am J Surg 2008; 195: 53-60. [CrossRef]

24. Dent DM, Madden MV, Price SK. Randomized comparison of R1 and R2 gastrectomy for gastric carcinoma. Br J Surg 1988; 75: 110-2. [CrossRef]

25. Roukos DH, Lorenz M, Karakostas K, Paraschou P, Batsis C, Kappas AM. Pathological serosa and node-based classification accurately predicts gastric cancer recurrence risk and outcome, and determines potential and limitation of a Japanese-style extensive surgery for Western patients: a prospective with quality control 10-year follow-up study. Br J Cancer 2001; 84: 1602-9. [CrossRef]

26. Roviello F, Marrelli D, Morgagni P, on behalf of the Italian Research Group for Gastric Cancer. Survival benefit of extended D2 lymphadenectomy in gastric cancer with involvement of second level lymph nodes: a longitudinal multicenter study. An Surg Oncol 2002; 9: 894900. [CrossRef]

27. Kodera Y, Sasako M, Yamamoto S, Sano T, Nashimoto A, Kurita A, on behalf of the Gastric Cancer Study Group of Japan Clinical Oncology Group. Identification of risk factors for the development of complications following extended and superextended lymphadenectomies for gastric cancer. Br J Surg 2005; 92: 1103-9. [CrossRef]

28. Kunisaki C, Shimada H, Yamaoka H, Takahashi M, Ookubo K, Akiyama H. Indications for paraaortic lymph node dissection in gastric cancer patients with paraaortic lymph node involvement. Hepatogastroenterology 2000; 47: 586-9. [CrossRef]

29. Isozaki H, Okajima K, Fujii K, Nomura E, Izumi M, Mabuchi H. Effectiveness of paraaortic lymph node dissection for advanced gastric cancer. Hepatogastroenterology 1999; 46: 549-54. [CrossRef]

30. Yonemura Y, Katayama K, Kamata T, Fushida S, Segawa M, Ooyama S. Surgical treatment of advanced gastric cancer with metastasis in para-aortic lymph node. Int Surg 1991; 76: 222-5. [CrossRef]

31. Kitamura M, Arai K, Iwasaki Y. Clinico-pathological studies on para-aortic lymph node metastasis and postoperative quality of life in gastric cancer patients. Jpn J Gastroenterol Surg 1995; 28: 923-6. [CrossRef]

32. Marrelli D, Pedrazzani C, Neri A, Corso G, DeStefano A, Pinto E, et al. Complications after extended (D2) and superextended (D3) lymphadenectomy for gastric cancer: analysis of potential risk factors. Ann Surg Oncol 2007; 14(1): 25-33. [CrossRef]

33. Gunther K, Horbach T, Merkel S, Meyer M, Schnell U, Klein P, Hohenberger W. D3 lymph node dissection in gastric cancer: evaluation of postoperative mortality and complications. Surg Today 2000; 30: 7005. [CrossRef]

34. Bostanci EB, Kayaalp C, Ozogul Y, Aydin C, Atalay F, Akoglu M. Comparison of complications after D2 and D3 dissection for gastric cancer. Eur J Surg Oncol 2004; 30: 20-25. [CrossRef]

35. Japanese Gastric Cancer Association. Japanese gastric cancer treatment guidelines 2018 (5 $5^{\text {th }}$ edition). Gastric Cancer 2020; 10.1007/ s10120-020-01042-y. [CrossRef]

36. Sasako M, Sano T, Yamamoto S, Kurokawa Y, Nashimoto A, Kurita A, et al. D2 lymphadenectomy alone or with para-aortic nodal dissection for gastric cancer. England J Med 2008; 359(5): 453-62. [CrossRef] 
37. Briasoulis E, Liakakos T, Dova L, Fatouros M, Tsekeris P, Roukos DH, et al. Selecting a spesific pre-or postoperative adjuvant theraphy for individual patients with operable gastric cancer. Expert Rev Anticancer Ther 2006; 6: 931-9. [CrossRef]

38. Liakakos T, Roukos DH. More controversy than ever: challenges and promises towards personalized treatment of gastric cancer. Ann Surg Oncol 2008; 15(4): 956-60. [CrossRef]

39. Ozmen MM, Zulfikaroglu B, Kucuk NO, Ozalp N, Aras G, Koseoglu T, et al. Lymphoscintigraphy in detection of the regional lymph node involvement in gastric cancer. Ann R Coll Surg Engl 2006; 88(7): 632-8. [CrossRef]

40. Ozmen MM, Ozmen F, Zulfikaroglu B. Lymph nodes in gastric cancer. J Surg Oncol 2008; 98(6): 476-81. [CrossRef]

41. Kulig J, Popiela T, Kolodziejczyk P, Sierzega M, Szczepanik A, on behalf of the Polish Gastric Cancer Study Group. Standard D2 versus extended D2 (D2+) lymphadenectomy for gastric cancer: an interim safety analysis of a multicenter, randomized, clinical trial. Am J Surg 2007; 193: 10-5. [CrossRef]

42. Danielson H, Kokkola A, Kiviluoto T, Siren J, Louhimo J, Kivilaakso E, et al. Clinical outcome after D1 vs D2-3 gastrectomy for treatment of gastric cancer. Scand J Surg 2007; 96: 35-40. [CrossRef]

43. Kunisaki C, Akiyama H, Nomura M, Matsuda G, Otsuka Y, Ono H, et al. Comparison of surgical results of D2 vs D3 gastrectomy (para-aortic lymph node dissection) for advanced gastric carcinoma: a multi-institutional study. Ann Surg Oncol 2006; 13(5): 659-67. [CrossRef]

44. Roukos DH, Kappas AM. Perspectives in the treatment of gastric cancer. Nat Clin Pract Oncol 2005; 2: 98-107. [CrossRef]

45. Cuschieri A, Weeden S, Fielding J, Bancewicz J, Craven J, Joypaul V, et al. Patient survival after D1 and D2 resections for gastric cancer: long-term results of the MRC randomized surgical trial. Surgical Cooperative Group. Br J Cancer 1999; 79: 1522-30. [CrossRef]

46. Wu CW, Hsiung CA, Lo SS, Hsieh MC, Shia LT, Whang-Peng J. Randomized clinical trial of morbidity after D1 and D3 surgery for gastric cancer. Br J Surg 2004; 91: 283-7. [CrossRef]

47. Kiyokawa T, Fukagawa T. Recent trends from the results of clinical trials on gastric cancer surgery. Cancer Communications 2019; 39(1): 11. [CrossRef]
48. Zhang YX, Yang K. Significance of nodal dissection and nodal positivity in gastric cancer. Translational Gastroenterology and Hepatology 2020; 5. [CrossRef]

49. Bencivenga M, Verlato G, Mengardo V, Scorsone L, Sacco M, Torroni $L$, et al. Is There Any Role for Super-Extended Limphadenectomy in Advanced Gastric Cancer? Results of an Observational Study from a Western High Volume Center. Journal of clinical medicine 2019; 8(11); 1799. [CrossRef]

50. Liang H, Deng J. Evaluation of rational extent lymphadenectomy for local advanced gastric cancer. Chinese Journal of Cancer Research 2016; 28(4); 397. [CrossRef]

51. Dong YP, Deng JY. Advances in para-aortic nodal dissection in gastric cancer surgery: A review of research progress over the last decade. World J Clin Cases 2020; 8(13):2703. [CrossRef]

52. Persiani R, Rausei S, Biondi A, Boccia S, Cananzi F, D'Ugo D. Ratio of metastatic lymph nodes: impact on staging and survival of gastric cancer. Eur J Surg Oncol 2008; 34(5): 519-24. [CrossRef]

53. Bouvier AM, Haas O, Piard F, Roignot P, Bonithon-Kopp C, Faivre J. How many nodes must be examined to accurately stage gastric carcinomas? Results from a population based study. Cancer 2002; 1(94): 2862-6. [CrossRef]

54. Inoue K, Nakane Y, liyama H, Sato M, Kanbara T, Nakai K, et al. The superiority of ratio-based lymph node staging in gastric carcinoma. Ann Surg Oncol 2002; 9: 27-34. [CrossRef]

55. Schwarz RE, Smith DD. Clinical impact of lymphadenectomy extent in resectable gastric cancer of advanced stage. Ann Surg Oncol 2007; 14(2): 317-28. [CrossRef]

56. Shen JY, Kim S, Cheong JH, Kim YI, Hyung WJ, Choi WH, et al. The impact of total retrieved lymph nodes on staging and survival of patients with pT3 gastric cancer. Cancer 2007; 110(4): 745-51. [CrossRef]

57. Verlato G, Marrelli D, Accordini S, Bencivenga M, Di Leo A, Marchet A, Petrioli R, Zoppini G, Muggeo M, Roviello F, de Manzoni G. Short-term and long-term risk factors in gastric cancer. World J Gastroenterol 2015;21(21):6434-43. [CrossRef]

58. de Manzoni G, Verlato G, Bencivenga M, Marrelli D, Di Leo A, Giacopuzzi S, Cipollari C, Roviello F. Impact of super-extended lymphadenectomy on relapse in advanced gastric cancer. Eur J Surg Oncol 2015; 41(4): 534-40. [CrossRef] 


\section{ORIJINAL ÇALIŞMA-ÖZET}

Turk J Surg 2021; 37 (1): 49-58

\section{İleri evre mide kanserlerinde D2 ve D2+ para-aortik lenf nodu diseksiyonu sonuçlarının karşılaştırılması}

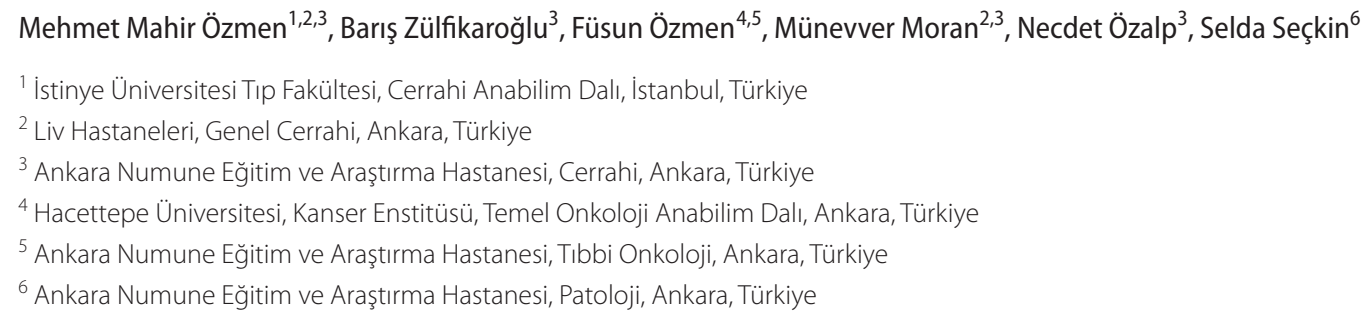

\section{ÖZET}

Giriş ve Amaç: Mide kanseri dünya çapında yaygın bir malignitedir. Disiplinler arası işbirliği ile etkili tedavi önemlidir ve cerrahi hala önemli bir rol oynamaktadır.

Gereç ve Yöntem: Kliniğimizde on yıl içinde 355 hastaya mide kanseri teşhisi kondu. Medyan yaşı 58 (23-83) olan 162 hasta çalışmaya uygundu. D2'de 107 hasta ve D2 lenfadenektomi artı para-aortik lenf nodu (PALN) diseksiyon grubunda 55 hasta vardı. İki grup komplikasyon, morbidite, mortalite ve uzun süreli sağkalım açısından karşılaştırıldı.

Bulgular: Hastanede kalış süresi D2 için 12 (8-34) gün ve D2+ PALND için 14 (8-42) gündü. Toplam operatif mortalite sayısı 8/162 (\%5) idi ve gruplar arasında farklı değildi. 20 hastada (\%18) D2 grubunda komplikasyon, 9 hastada (\%17) D2+ PALND grubunda komplikasyon vardı. Genel sağkalım gruplar arasında da benzerdi, ancak T3-T4 tümörleri olan hastalar, evre IIIA ve IIIB hastalığı olan hastalar ve daha yüksek PLN/TLN oranı olan hastalar D2+ PALN diseksiyonu ile daha iyi sağkalım gösterdi. İnvazyon derinliği, PLN, PLN/TLN oranı, evre ve LND'nun bağımsız prognostik değişkenler olduğunu bulduk.

Sonuç: Bu çalışma, D2+ PALN diseksiyonunun ileri evre mide kanseri için, postoperatif morbidite ve mortaliteyi arttırmadan deneyimli cerrahlar tarafından standart bir D2 diseksiyonu kadar güvenli bir şekilde yapılabileceğini göstermiştir. D2+ PALN diseksiyonu, sağkalım oranını arttırdığı için hastalığın ileri evresinde (IIIA-IIIB) tercih edilmelidir.

Anahtar Kelimeler: Illeri evre mide kanseri, D2 lenf nodu disseksiyonu, D2+palnd lenf nodu disseksiyonu, prognoz

DOI: $10.47717 /$ turkjsurg.2020.4931 